\title{
Acute-phase inter-alpha-trypsin inhibitor heavy chain 4 (ITIH4) levels in serum and milk of cows with subclinical mastitis caused by Streptococcus species and coagulase-negative Staphylococcus species
}

\author{
Lourdes Soler, ${ }^{1,2}$ Roman Dąbrowski, ${ }^{3}$ Natalia García, ${ }^{2}$ María A. Alava, ${ }^{2}$ Fermín Lampreave, ${ }^{2}$ Matilde Piñeiro, ${ }^{1}$ \\ Władysław Wawron, ${ }^{3}$ Marek Szczubiał, ${ }^{3}$ and Mariola Bochniarz ${ }^{3 *}$ \\ ${ }^{1}$ Acuvet Biotech, C/ Bari 25 dpdo, 50197 Zaragoza, Spain \\ ${ }^{2}$ Departamento de Bioquímica y Biología Molecular y Celular, Facultad de Ciencias, Universidad de Zaragoza, Pedro Cerbuna 12, \\ 50009 Zaragoza, Spain \\ ${ }^{3}$ Department and Clinic of Animal Reproduction, Faculty of Veterinary Medicine, University of Life Sciences, Gleboka 30, 21-612 Lublin, Poland
}

\section{ABSTRACT}

The aim of the study was to investigate the concentrations of acute-phase inter- $\alpha$-trypsin inhibitor heavy chain 4 (ITIH4) in serum and milk of cows with subclinical mastitis caused by Streptococcus spp. (STR) and coagulase-negative Staphylococcus spp. (CNS) and healthy cows. The blood and milk samples were obtained from 60 mid-lactation, multiparous Holstein-Friesian cows from 7 herds in the Lublin region of Poland. In the milk samples from 40 cows with subclinical mastitis, Streptococcus spp. and CNS were isolated. The ITIH4 was significantly higher in serum of cows with subclinical mastitis caused both by STR and CNS compared with healthy cows. One hundred percent of animals infected with Streptococcus spp. and $89 \%$ of animals infected with Staphylococcus spp. showed ITIH4 concentration in sera higher than 0.5 $\mathrm{mg} / \mathrm{mL}$. The concentration of ITIH4 in milk also was significantly higher in cows with subclinical mastitis caused by Streptococcus spp. and Staphylococcus spp. compared with the control group. Seventy percent of cows infected by STR and CNS showed ITIH4 concentration in milk higher than $2.5 \mu \mathrm{g} / \mathrm{mL}$. Milk ITIH4 concentration higher than $5 \mu \mathrm{g} / \mathrm{mL}$ was found in $55 \%$ of animals infected with Streptococcus spp. and in $40 \%$ of animals infected with Staphylococcus spp. No statistically significant differences were observed in ITIH4 concentrations both in serum and in milk between the studied unhealthy animal groups. These results suggest that ITIH4 may be used in the future as a novel diagnostic marker in serum and in milk of subclinical mastitis in cows.

Key words: mastitis, cow, Streptococcus species, coagulase-negative Staphylococcus species, inter- $\alpha-$ trypsin inhibitor heavy chain 4

Received April 6, 2018.

Accepted August 30, 2018.

*Corresponding author: mariolabochniarz@interia.pl

\section{INTRODUCTION}

Mastitis is an endemic disease on dairy farms all over the world and is an important cause of less efficient milk production because of milk production losses, milk of less quality, drugs use, discarded milk, veterinarian, labor, and culling costs. Inflammation of the mammary gland in cows can be caused by over 150 species of microorganisms, of which the dominant role is played by Staphylococcus spp., mainly CNS (Waller et al., 2011; Bochniarz et al., 2013; De Visscher et al., 2016; Condas et al., 2017) and by Streptococcus spp. (Keefe, 1997; Whist et al., 2007). These pathogens may cause both clinical and subclinical mastitis, which is a huge problem in dairy herds. Subclinical mastitis infections do not cause any visible changes in milk or udder appearance, making it difficult to detect, and if untreated in the long term lead to the development of clinical mastitis or changes typical of the chronic process (Sinha et al., 2014). Research presented at the 2015 National Mastitis Council Annual Meeting concluded that cost of subclinical mastitis often is greater than that of clinical mastitis (Kirkpatrick and Olson, 2015). Although the milk appears normal, cows with subclinical mastitis will produce less milk, and the quality of the milk will be reduced. In addition, infected cows can be a source of infection to other animals in the herd (Hiitiö et al., 2017).

The body's reaction to an infecting factor damaging tissue or organ structures is manifested as an inflammatory reaction. The acute phase response of an organism to infection, tissue injury, and the process of inflammation, apart from local reactions, also develops a systemic response characterized by fever, leukocytosis, and a significant change in the concentration of some plasma proteins denoted acute phase proteins (APP; Baumann and Gauldie, 1994; González-Ramón et al., 2000). These proteins are very important diagnostic and prognostic factors in infections and other homeostasis disturbances. The acute-phase response 
is initiated by inflammation-related cytokines, such as IL-6 and tumor necrosis factor, released by activated macrophages (Eckersall et al., 2001; Hagiwara et al., 2001; Murata et al., 2004).

Acute phase proteins, such as serum amyloid A and haptoglobin, have been studied extensively in cattle, particularly as potential biomarkers of mastitis in serum and milk (Grönlund et al., 2003; Nazifi et al., 2008; Miglio et al., 2013). However, not much is known in this species about the new APP inter- $\alpha$-trypsin inhibitor heavy chain 4 (ITIH4; Piñeiro et al., 2004), which was first detected in pigs under acute inflammation. The studies of Lampreave et al. (1994) confirmed that pig MAP (major APP) is homologous to human serum protein denoted plasma kallikrein-sensitive glycoprotein of molecular mass $120 \mathrm{kDa}(\mathbf{P K}-120)$ or inter- $\alpha-$ trypsin inhibitor human-related protein (Nishimura et al., 1995; Saguchi et al., 1995; González-Ramón et al., 2000). The AA sequence obtained from the pig, and human proteins show significant homology for over twothirds of the amino-terminal sequences with the heavy chains $(\mathrm{H} 1, \mathrm{H} 2$, and $\mathrm{H} 3)$ of the inter- $\alpha$-trypsin inhibitor (ITI) protein family (Saguchi et al., 1995; Hashimoto et al., 1996). For this reason, the new protein pigMAP/PK-120/inter- $\alpha$-trypsin inhibitor human-related protein has been recognized as a new member of the heavy-chain ITI family, and further named as ITIH4 (Salier et al., 1996). In contrast, the homology with the other $\mathrm{H}$ chains is low for one-third of the carboxyterminal sequence of the polypeptide chain (Nishimura et al., 1995; Salier et al., 1996). In contrast to the heavy chains, H1, H2, and H3, which are bound through glycosaminoglycan bridges to bikunin (which contains 2 Kunitz-type protease inhibitor domains), H4 does not have a sequence for bikunin assembling (Hashimoto et al., 1996).

In previous studies, bovine ITIH4 was detected in the milk and whey of cows with clinical mastitis using proteomic techniques (Alonso-Fauste et al., 2012; Huang et al., 2014).

The aim of this study was to investigate the concentrations of the APP ITIH4 in serum and milk of cows with subclinical mastitis caused by Streptococcus spp. and CNS and healthy cows.

\section{MATERIALS AND METHODS}

\section{Animals and Management}

Quarter milk samples were aseptically collected during usual morning milking from each milk-producing cow from 7 herds of various housing systems ( 5 freestall or loose, and 2 tiestall housing systems) in the Lublin region in Poland. Cows were milked twice a day and had daily milk yield of 14.2 to $54.4 \mathrm{~kg}$ (median $34.4 \mathrm{~kg}$ ). Overall, 1,356 quarter milk samples were obtained from 339 lactating cows from the 7 farms (herd number $1, \mathrm{n}$ $=57$; number $2, \mathrm{n}=24$; number $3, \mathrm{n}=25$; number $4, \mathrm{n}$ $=31$; number $5, \mathrm{n}=44$; number $6, \mathrm{n}=86$; and number $7, \mathrm{n}=72$ lactating cows, respectively). Milk samples were delivered with a maximum transport time of 1 $\mathrm{h}$ at a temperature of $4^{\circ} \mathrm{C}$ to laboratory examination. The SCC was measured in fresh milk by fluoro-optoelectronic cell counting (SomaCount FC Automatic, Bentley Instruments Inc., Chaska, MN).

\section{Laboratory Analysis}

Milk was bacteriologically tested according to National Mastitis Council (2004) guidelines. Milk samples brought to room temperature were thoroughly mixed and a volume of $0.01 \mathrm{~mL}$ of milk was streaked on agar medium (BTL, Łódź, Poland) supplemented with sterile defibrinated sheep blood ( $5 \%$ of the agar solution volume; 1 sample per one agar plate). After $24 \mathrm{~h}$ of incubation at $37^{\circ} \mathrm{C}$ in aerobic conditions, pathogens were initially identified based on colony morphology, catalase test, and Gram-stained microscopic specimens. Colonies that were found to be gram-positive, and catalase-negative cocci (the genera Streptococcus and Enterococcus), were cultivated on Esculin Blood Agar (Oxoid, Basingstoke, UK). Esculin-hydrolyzing cultures were further cultivated on Kanamycin Esculin Azide Agar (Oxoid) to differentiate Streptococcus from Enterococcus spp. Colonies that were found to be grampositive and catalase-positive cocci were streaked on selective agar for staphylococci Mannitol Salt Agar (Chapman Medium, Oxoid) and incubated at $37^{\circ} \mathrm{C}$ for $24 \mathrm{~h}$ to confirm they are Staphylococcus spp. To distinguish coagulase-negative from coagulase-positive Staphylococcus spp., a coagulase test (Sigma Aldrich, St. Louis, MO) was used. Staphylococci were discriminated from other minor pathogens such as Bacillus spp., Corynebacterium spp. based on colony color and shape (round, glossy), and Gram staining.

\section{Selection of Animals to Study}

Animals without systemic signs (such as a lack of appetite, depressed rumen function, or body temperature greater than $39.3^{\circ} \mathrm{C}$ ), with a cow SCC $>200,000$ cells/ $\mathrm{mL}$ and positive bacteriological culture results were considered as having subclinical mastitis (Moon et al., 2007).

Somatic cell count $>200,000$ cells $/ \mathrm{mL}$ of milk was affirmed in $146(10.8 \%)$ quarter milk samples obtained from $111(32.7 \%)$ cows. The presence of microorganisms in bacteriological analysis was recorded in 124 quarters 
milk samples from 97 cows ( 74 cows: 1 quarter; 19 cows: 2 quarters; and 4 cows: 3 quarters) with SCC $>200,000$ cells $/ \mathrm{mL}$. Collection of blood and quarter milk samples was described in a previous study (Bochniarz et al., 2018). Inclusively, in 22 quarter milk samples with SCC $>200,000$ cells $/ \mathrm{mL}$ obtained from 14 cows, growth of microorganisms was not detected. Cows with elevated SCC in milk but negative bacteriological examination and cows in which, apart from Streptococcus spp. or CNS, other microorganisms were also found in the bacteriological culturing of milk were not qualified for the study. Aside from that, cows with a visible teat injury and cows treated for other disease were excluded. Additional selection criteria were cows with only 1 quarter affected.

Any lactating dairy cow with subclinical mastitis, according to the previous test, and only one infected quarter (the other quarters being culture-negative) was considered for enrolment in the study. Forty cows were selected to study in which no clinical signs of mastitis were found, and SCC >200,000 cells $/ \mathrm{mL}$ (395,000-1,656,000 cells/mL) and growth of Streptococcus spp. or CNS was detected in only 1 quarter of the udder. In the remaining 3 quarters from these cows, SCC $<200,000$ cells $/ \mathrm{mL}$ and negative bacteriological analysis was recorded.

For the control group (HE group), 20 cows without mastitis were selected that did not show any clinical signs of mastitis, nor abnormalities in the udder or milk. The health status was confirmed by clinical examination of cows, negative bacteriological analysis of milk, and low average level of SCC $(<100,000$ cells $/ \mathrm{mL})$ in all 4 quarter milk samples from each cow. Hematological examination of blood of cows was performed using Scil ABC+ Vet Animal Hematology Analyzer (Horiba, Kyoto, Japan) to obtain measurements of constituents of the blood: hemoglobin, erythrocytes, white blood cells, hematocrit, and platelets. Clinical examination of cows and macroscopic evaluation of milk were carried out before collection of milk samples for bacteriological testing. One sample of milk (random choice from 4 quarter milk samples of the cow) and one sample of blood from each control cow were qualified for evaluation of level of ITIH4.

Milk and serum samples were stored at $-80^{\circ} \mathrm{C}$ until the analysis of ITIH4 was performed.

\section{Measurements of ITIH4 in Serum and Milk Samples}

The ITH4 was measured in serum and milk samples using a species-specific ELISA kit (Acuvet ELISA ITIH4, Acuvet Biotech, Zaragoza, Spain), previously validated (Soler et al., 2018) according to the manu- facturer's instructions. Serum samples were diluted $1 / 5,000$, and milk samples were diluted $1 / 100$. For serum samples the intraassay coefficients of variations $(\mathbf{C V})$ were lower than $8 \%$ and interassay $\mathrm{CV}$ were lower than $10 \%$. For milk samples intraassay CV were lower than $7 \%$ and interassay CV were lower than $11 \%$. The limit of detection of the assay, calculated from the mean +3 standard deviations of a blank sample composed of sample dilution buffer, was of $0.013 \mu \mathrm{g} / \mathrm{mL}$ (Soler et al., 2018). Taking into account the dilution used for the analysis of serum and milk samples, the limits of detection were $1.3 \mu \mathrm{g} / \mathrm{mL}$ for milk and 0.066 $\mathrm{mg} / \mathrm{mL}$ for serum samples.

\section{Statistical Analysis}

Statistical methods were used to compare serum and milk concentrations of ITIH4 in cows with subclinical mastitis caused by Streptococcus spp., CNS, and healthy cows. For the tested groups of cows, the descriptive statistical parameters calculated were minimum and maximum values, median value, mean, and standard deviation. Using a Shapiro-Wilk test there was no normal distribution of characteristic values in each group, so the Mann-Whitney test was used to compare these characteristics for 2 independent trials. For analysis of correlations between milk and serum ITIH4 and milk ITIH4 and SCC, Spearman coefficients of correlation were calculated. $P<0.05$ was considered significant. The calculations were performed using statistical package GraphPad Prism 5.0 (GraphPad Software Inc., La Jolla, CA).

\section{Ethics Approval and Consent to Participate}

The research protocols used in the current study were approved by the Veterinary Department of the University of Lublin (permission number 40/2014, 04.11.2014), according to the European Council Directives regarding the protection of animals used for experimental purposes.

\section{RESULTS}

The present study indicates that ITIH4 was significantly higher in serum of cows with subclinical mastitis caused both by STR and CNS compared with healthy cows $(P<0.001$, Table 1 and Figure 1a). One hundred percent of animals infected with Streptococcus spp. and $89 \%$ of animals infected with Staphylococcus spp. showed an ITIH4 concentration in sera higher than 0.5 $\mathrm{mg} / \mathrm{mL}$. A value higher than the maximum level of ITIH4 in serum of healthy cows $(>0.9 \mathrm{mg} / \mathrm{mL})$ was 
Table 1. Descriptive statistics of the inter- $\alpha$-trypsin inhibitor heavy chain 4 (ITIH4) in serum from cows with subclinical mastitis caused by Streptococcus spp. (STR) or CNS, and healthy cows (HE) ${ }^{1}$

\begin{tabular}{lcccccc}
\hline & \multicolumn{5}{c}{ ITIH4 $(\mathrm{mg} / \mathrm{mL})$} \\
\cline { 2 - 6 } Item & $\mathrm{N}$ & Mean & $\mathrm{SD}$ & Median & Min & Max \\
\hline Serum HE & 20 & 0.58 & 0.18 & 0.52 & 0.27 & 0.9 \\
Serum CNS & $19^{2}$ & 0.90 & 0.90 & 0.86 & 0.39 & 1.53 \\
Serum STR & 20 & 1.12 & 1.12 & 1.06 & 0.61 & 1.65 \\
\hline${ }^{1}$ Data are presented as mean, SD, median, minimum (Min), and maximum (Max) & values. N = number of \\
samples. \\
${ }^{2}$ Serum samples were available from only 19 animals in the CNS group.
\end{tabular}

found in $75 \%$ of serum samples of cows suffering from mastitis caused by Streptococcus spp. and in $47 \%$ of serum samples of cows with CNS mastitis.

The concentration of ITIH4 in milk also was significantly higher in cows with subclinical mastitis caused by Streptococcus spp. $(P<0.05)$ and Staphylococcus spp. $(P<0.05)$ compared with the control group (Table 2 and Figure 1b). Seventy percent of cows infected by STR and CNS showed ITIH4 concentration in milk higher than $2.5 \mu \mathrm{g} / \mathrm{mL}$. Milk ITIH4 concentration higher than $>5 \mu \mathrm{g} / \mathrm{mL}$ was found in $55 \%$ of animals infected with Streptococcus spp. and in $40 \%$ of animals infected with Staphylococcus. Moreover, values of this protein higher than its maximum level found in the milk of healthy cows $(>9.08 \mu \mathrm{g} / \mathrm{mL})$ were recorded in $40 \%$ of cow milk samples from STR mastitis and $25 \%$ milk samples from CNS mastitis.

No statistically significant difference was observed in ITIH4 concentrations in serum or milk of the studied unhealthy animal groups $(P>0.05$, Tables 1 and 2 , Figure $1 \mathrm{a}$ and $1 \mathrm{~b})$.

Table 3 shows the analysis of correlations between ITIH4 in serum and milk samples, and between milk
ITIH4 and SCC. The correlation between serum ITIH4 and milk ITIH4 was moderate for the control healthy group $(\mathrm{r}=0.66)$ and the total population tested $(\mathrm{r}=$ 0.6 ) and weak for animals with subclinical mastitis ( $\mathrm{r}$ $=0.48$ ). A moderate correlation was observed between SCC and milk ITIH4 for the control group and for the total of animals with subclinical mastitis $(\mathrm{r}=0.51$ and 0.59 , respectively), whereas the correlation was strong for the STR group $(\mathrm{r}=0.80$, Figure $2 \mathrm{a}$ and $2 \mathrm{~b})$. No correlation was observed for the CNS group.

\section{DISCUSSION}

In the present study, the concentration of ITIH4 was investigated for the first time in serum and milk obtained from cows with subclinical mastitis caused by Streptococcus spp. and CNS.

The ITIH4 is a liver-derived member of the ITI family with diverse functions as an anti-apoptotic and matrix-stabilizing molecule that is important throughout development. Interaction of ITI members with components of the extracellular matrix has been described (Bost et al., 1998). A possible role of ITIH4 related
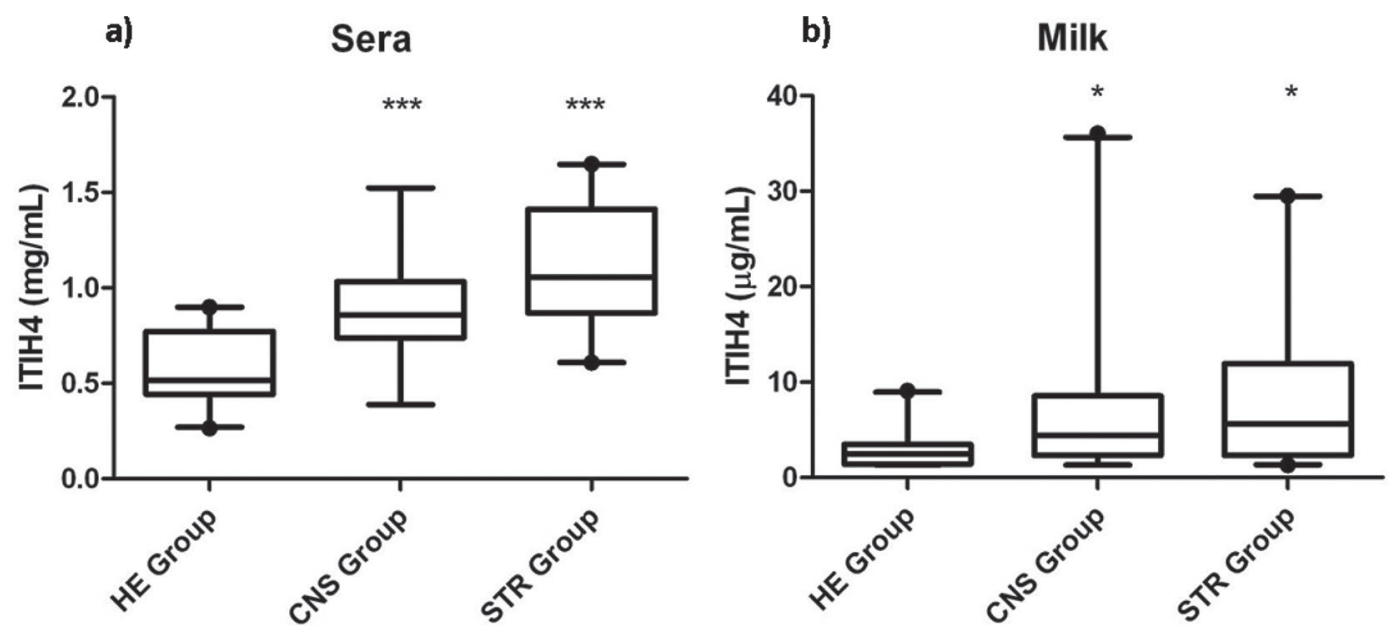

Figure 1. Boxplots showing inter- $\alpha$-trypsin inhibitor heavy chain 4 (ITIH4) values in (a) sera and (b) milk samples. Interquartile range (25th to 75 th percentile) is represented by the box, the median is marked with a line, and the whiskers show maximum and minimum values. $* * * P<$ 0.001, $* P<0.05$ : comparison between CNS or Streptococcus spp. (STR) and healthy (HE) group. 
Table 2. Descriptive statistics of the inter- $\alpha$-trypsin inhibitor heavy chain 4 (ITIH4) in milk from cows with mastitis caused by Streptococcus spp. (STR) or CNS, and healthy cows (HE) ${ }^{1}$

\begin{tabular}{lcccccc}
\hline & \multicolumn{7}{c}{ ITIH4 $(\mathrm{mg} / \mathrm{mL})$} \\
\cline { 2 - 7 } Item & $\mathrm{N}$ & Mean & $\mathrm{SD}$ & Median & Min & Max \\
\hline Milk HE & 20 & 2.98 & 1.97 & 2.50 & 1.32 & 9.08 \\
Milk CNS & 20 & 7.50 & 9.01 & 4.42 & 1.32 & 46.03 \\
Milk STR & 20 & 8.90 & 5.66 & 5.66 & 1.32 & 29.51 \\
\hline
\end{tabular}

${ }^{1}$ Data are presented as mean, SD, median, minimum (Min), and maximum (Max) values. $\mathrm{N}=$ number of samples.

to modulation of cell migration and proliferation during the development of the acute-phase response has been discussed (Bhanumathy et al., 2002; Piñeiro et al., 2004). Bhanumathy et al. (2002) suggested that the markedly high expression of ITIH4 in early liver development and in explants treated with IL-6 suggests a prominent role for this protein at key points in liver formation. Aside from this, ITIH4 may play an important role in liver regeneration as shown by the rise in ITIH4 mRNA 30 min after partial hepatectomy.

Expression of ITIH4 is induced under different pathological states of host in humans (Piñeiro et al., 1999). Previous studies demonstrated elevations in the level of this protein in serum of patients undergoing acute phase processes such as myocardial infarction and unstable angina or programmed surgery, confirming its role as an APP (Piñeiro et al., 1999). In turn, Lee et al. (2015) stressed that ITIH4 is a significant biomarker to assess particulate matter $\left(\mathrm{PM}_{10}\right)$ in patients with chronic obstructive pulmonary disease. An important indicator of the disease process may also be a decrease in ITIH4 level in the blood serum. Kashyap et al. (2009) showed that ITIH4 $120 \mathrm{~K}$ protein was completely absent in patients with acute ischemic stroke as compared with those in the control group, and serum levels returned to normal in acute ischemic stroke patients as their condition improved. Research by other authors shows

Table 3. Study of correlations between serum inter- $\alpha$-trypsin inhibitor heavy chain 4 (ITIH4) and milk ITIH4, and between SCC and milk ITIH4, for each individual group of the study (HE = healthy, CNS, and STR = Streptococcus spp.), animals with subclinical mastitis (CNS and STR), and all the animals ${ }^{1}$

\begin{tabular}{lccc}
\hline & & \multicolumn{2}{c}{ Spearman coefficient $(\mathrm{r})$} \\
\cline { 3 - 4 } Group & $\mathrm{n}$ & $\begin{array}{c}\text { Serum ITIH4 vs. } \\
\text { milk ITIH4 }\end{array}$ & $\begin{array}{c}\text { SCC vs. } \\
\text { milk ITIH4 }\end{array}$ \\
\hline HE & 20 & 66 & 0.51 \\
CNS & 19 & NS & NS \\
STR & 20 & 0.51 & 0.8 \\
Subclinical mastitis & 39 & 0.48 & 0.59 \\
All animals & 59 & 0.60 & 0.58 \\
\hline
\end{tabular}

${ }^{1} \mathrm{r}=$ value of Spearman coefficient for significant correlations $(P<$ $0.05)$. NS $=$ not significant correlation between studied variables.
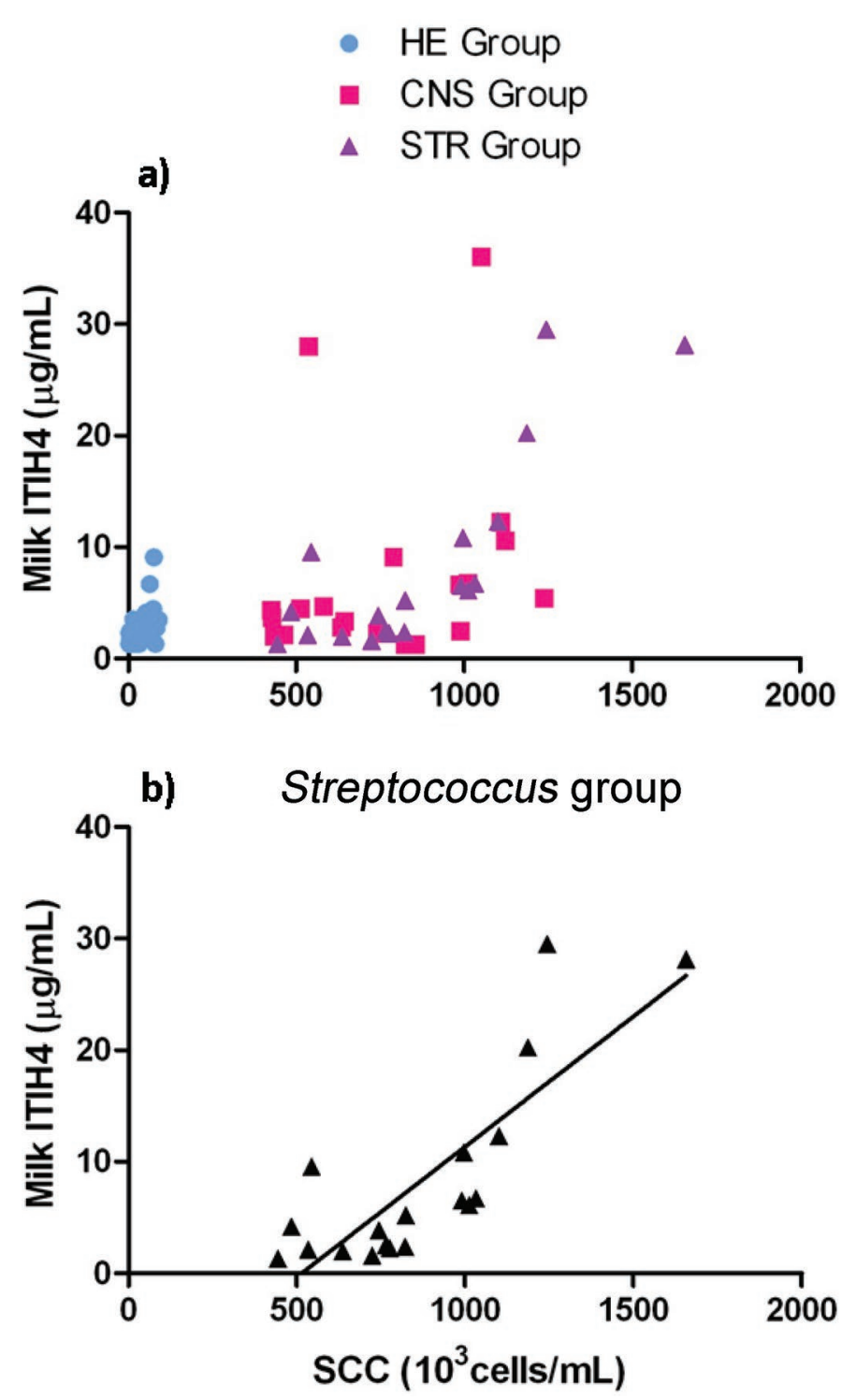

Figure 2. Plots of milk inter- $\alpha$-trypsin inhibitor heavy chain 4 (ITIH4) concentration and SCC: (a) distribution of ITIH4 concentration as a function of the SCC, (b) correlation between ITIH4 concentration and SCC in the Streptococcus spp. (STR) group. HE = healthy control group, circles; CNS = squares; and STR = triangles. 
that ITIH4 may also have potential antiviral properties against chronic hepatitis C virus. Sira et al. (2014) found that hepatitis $\mathrm{C}$ viremia was lower in patients with higher serum ITIH4 levels. Previous studies indicate that ITIH4 play a particularly important role not only in inflammation but also in carcinogenesis. Subbannayya et al. (2015) described the increased level of ITIH4 in gastric adenocarcinoma in humans.

The ITIH4 was described for the first time in 1994 and identified as a major APP in pigs (pig MAP) by Lampreave et al. (1994). The studies performed showed that the concentration of pig MAP can increase up to 30 times during acute inflammation processes (GonzálezRamón et al., 1995). Piñeiro et al. (2004) also demonstrated that ITIH4 is an APP in cattle. The ITIH4 was isolated from the serum of heifers with experimentally induced "summer mastitis." All heifers after experimental infection of the udder developed clinical signs of moderate to severe mastitis, including fever, increased pulse rate, udder swelling, and changes in the milk. In all animals, the concentration of ITIH4 in serum was significantly higher than before infection (3-4 times in cows with milder clinical mastitis, and 6 to 12 times in cows with severe clinical mastitis). Maximum level of this protein in serum was found at $72 \mathrm{~h}$ after bacterial infection (Piñeiro et al., 2004).

In the present study, we also found an increase in ITIH4 in both serum and milk of unhealthy cows in both streptococcal and CNS mastitis compared with healthy cows. It should be emphasized that milk and serum samples came from cows with subclinical mastitis characterized by a lack of both systemic and local symptoms in the mammary gland. In a previous study (Bochniarz et al., 2017), we recorded a significant increase in the level of milk amyloid A (MAA) in the milk of unhealthy cows affected by CNS-caused mastitis $(P<0.001)$, whereas we did not find a statistically significant difference in the level of SAA in the blood serum of unhealthy cows in comparison to the control group. However, this research indicates a significant increase in ITIH4 level not only in milk (2.5 times) but also in serum (1.5 times increase) in cows with subclinical mastitis caused by CNS compared with healthy cows. An even greater increase in concentration of ITIH4 was noted in milk and serum of cows suffering from subclinical mastitis caused by Streptococcus spp. (3 times and 2 times, respectively, compared with the healthy control group); however, it was not significantly different from the CNS group. Thus, there is a suspicion that in the case of subclinical mastitis, despite the absence of symptoms on the body of a cow such as fever, mechanisms of the systemic immune response are also triggered. Moreover, as occurs with amyloid A (Bochniarz et al., 2017), in this research we did not find a correlation between serum ITIH4 and milk ITIH4 in CNS mastitis, suggesting a local extrahepatic production of this protein, as has been reported for other APP (Hiss et al., 2004; Weber et al., 2006; Thielen et al., 2007). In our study a moderate correlation between ITIH4 in milk and serum samples was observed for cows infected with Streptococcus spp., as well as for the control samples. The degree of correlation was higher for the control samples $(r=0.66)$ than for the animals with mastitis $(\mathrm{r}=0.49)$. This finding and the strong correlation between SCC and milk ITIH4 in the streptococci group $(\mathrm{r}=0.80)$ suggest a local production of ITIH4. Thus, as occurs with haptoglobin, during mastitis presence of ITIH4 in milk could be a combination of extra-hepatic production in migrating somatic cells and mammary gland tissue (Hiss et al., 2004; Thielen et al., 2005, 2007; Lai et al., 2009) and leakage of serum protein produced by the liver, and the contribution of each factor may vary with different pathological conditions or with the causing agent of the mastitis. As occurs with haptoglobin (Lai et al., 2009), increased expression of ITIH4 in somatic cells obtained from the milk of a cow with clinical mastitis was previously reported by Andrés (2009). Increased expression of ITIH4 in the mammary gland of cows affected by mastitis caused by Staphylococcus aureus has also been recently described (Huang et al., 2014).

A correlation between SCC and APP has been reported in other studies. Nielsen et al. (2004) found that the concentration of haptoglobin and SAA in milk increased with increasing SCC. Akerstedt et al. (2007) reported a correlation between MAA or milk haptoglobin concentration and SCC. In that study, haptoglobin and MAA were more commonly present in quarter and composite milk samples with SCC above 550,000 cells/ $\mathrm{mL}$, and a correlation with SCC was found for these samples. These findings are consistent with our results. Similarly, in our study the correlation was mainly due to milk samples with SCC above 550,000 to $1,000,000$ cells $/ \mathrm{mL}$. However, the degree of correlation was higher for STR mastitis than for CNS mastitis, although the number of samples with a SCC in this range was similar. The divergence in the ITIH4 response in both infections might be related to the different causal bacteria. Although mostly focused on Escherichia coli versus Staphylococcus aureus, several studies have shown differences in leucocyte recruitment and immune reactions of the mammary gland associated with the pathogen causing the disease (Alnakip et al., 2014).

The main role of the acute phase reaction is to restore homeostasis in the organism by stimulating immune mechanisms. The interaction of various cellular 
and humoral immune response mechanisms is based on the transmission of cytokines stimulatory or inhibitory signals. Interleukin-6, which is considered to be the strongest stimulator of production and secretion of APP, plays a particularly important role (Song and Kellum, 2005). It should be emphasized that ITIH4, like the remaining members of the ITI family, has been demonstrated to be transcriptionally regulated by IL-6 (Sarafan et al., 1995; González-Ramón et al., 2000). Elevated levels of IL-6 have been associated with increased level of ITIH4 in several models in different species, including humans, pig, and mouse (Piñeiro et al., 1999; González-Ramón et al., 2000; Bhanumathy et al., 2002). Bhanumathy et al. (2002) showed that mouse ITIH4 significantly increased in liver explants treated with IL-6. This increase did not occur with IL-1 or tumor necrosis factor- $\alpha$ treatment. In our previous study (Bochniarz et al., 2017), using the same samples that were used in the present study, we noted a statistically significant increase in IL-6 levels in both milk and serum of cows with subclinical mastitis caused by CNS $(P<0.001)$. Thus, an association exists between elevated levels of IL-6 and elevated levels of ITIH4, in both serum and milk of cows with subclinical mastitis caused by CNS.

In conclusion, the present study showed an increase of ITIH4 level in milk and serum of cows with subclinical mastitis caused by Streptococcus spp. and CNS compared with the group of healthy cows. These results suggest that ITIH4 may be used in the future as a novel diagnostic marker for the detection of subclinical mastitis in serum and milk of cows, but further studies are necessary to explore its potential as a diagnostic tool, alone or in combination with other APP. The ability to detect mastitis early for prompt interventions can have a significant effect on milk production, milk quality, and herd health because it helps to avoid persistent udder infection and the spread of pathogens in dairy herds. In our opinion the present study provides new knowledge about ITIH4, but further studies are necessary to better characterize and understand the function of this protein in infectious diseases in mammary gland of cows.

\section{ACKNOWLEDGMENTS}

This work has been possible thanks to the support of research project RTC-20153885-2 [Ministerio de Economía y Empresas (MINECO), Spain/European Regional Development Fund (ERDF)]. Lourdes Soler was funded by MINECO programme Doctorado Industrial, Plan Estatal de Investigación Científica y Técnica y de Innovación 2013-2016, Resolución 16 Diciembre 2015.

\section{REFERENCES}

Akerstedt, M., K. Persson Waller, and A. Sternesjö. 2007. Haptoglobin and serum amyloid $\mathrm{A}$ in relation to the somatic cell count in quarter, cow composite and bulk tank milk samples. J. Dairy Res. 74:198-203.

Alnakip, M. E., M. Quintela-Baluja, K. Böhme, I. Fernandez-No, S. Caamaño-Antelo, P. Calo-Mata, and J. Barros-Velázquez. 2014. The immunology of mammary gland of dairy ruminants between healthy and inflammatory conditions. J. Vet. Med. 2014:659801.

Alonso-Fauste, I., M. Andrés, M. Iturralde, F. Lampreave, J. Gallart, and M. A. Alava. 2012. Proteomic characterization by 2-DE in bovine serum and whey from healthy and mastitis affected farm animals. J. Proteomics 75:3015-3030.

Andrés, M. 2009. Estudio bioquímico y fisiopatológico de la ITIH4, una nueva proteína de fase aguda positiva en la especie bovina. (Biochemical and Physiopathological study of ITIH4, a new positive acute phase protein in bovine). Doctoral thesis. Department of Biochemistry and Cellular Biology, University of Zaragoza, Spain.

Baumann, H., and J. Gauldie. 1994. The acute phase response. Immunol. Today 15:74-80.

Bhanumathy, C. D., Y. Tang, S. P. Monga, V. Katuri, J. A. Cox, B. Mishra, and L. Mishra. 2002. Itih-4, a serine protease inhibitor regulated in interleukin-6-dependent liver formation: Role in liver development and regeneration. Dev. Dyn. 223:59-69.

Bochniarz, M., T. Kocki, R. Dąbrowski, M. Szczubiał, W. Wawron, and W. Turski. 2018. Tryptophan, Kynurenine, Kynurenic acid concentrations and indoleamine 2,3-dioxygenase (IDO) activity in serum and milk of dairy cows with subclinical mastitis caused by coagulase-negative staphylococci (CNS). Reprod. Domest Anim. https://doi.org/10.1111/rda.13299.

Bochniarz, M., W. Wawron, and M. Szczubiał. 2013. Coagulase-negative staphylococci (CNS) as an aetiological factor of mastitis in cows. Pol. J. Vet. Sci. 16:487-492.

Bochniarz, M., B. Zdzisińska, W. Wawron, M. Szczubiał, and R. Dąbrowski. 2017. Milk and serum IL-4, IL-6, IL-10, and amyloid A concentrations in cows with subclinical mastitis caused by coagulase-negative staphylococci. J. Dairy Sci. 100:9674-9680.

Bost, F., M. Diarra-Mehrphour, and J. P. Martin. 1998. Inter-alphatrypsin inhibitor proteoglycan family. A group of proteins binding and stabilizing the extracellular matrix. Eur. J. Biochem. 252:339 346.

Condas, L. A. Z., J. De Buck, D. B. Nobrega, D. A. Carson, S. Naushad, S. De Vliegher, R. N. Zadoks, J. R. Middleton, S. Dufour, J. P. Kastelic, and H. W. Barkema. 2017. Prevalence of non-aureus staphylococci species causing intramammary infections in Canadian dairy herds. J. Dairy Sci. 100:5592-5612.

De Visscher, A., S. Piepers, F. Haesebrouck, and S. De Vliegher. 2016. Intramammary infection with coagulase-negative staphylococci at parturition: Species-specific prevalence, risk factors, and effect on udder health. J. Dairy Sci. 99:6457-6469.

Eckersall, P. D., F. J. Young, C. McComb, C. J. Hogarth, S. Safi, A. Weber, T. McDonald, A. M. Nolan, and J. L. Fitzpatrick. 2001. Acute phase proteins in serum and milk from dairy cows with clinical mastitis. Vet. Rec. 148:35-41.

González-Ramón, N., M. A. Alava, J. A. Sarsa, M. Piñeiro, A. Escartín, A. García-Gil, F. Lampreave, and A. Piñeiro. 1995. The major acute phase serum protein in pigs is homologous to human plasma kallikrein sensitive PK-120. FEBS Lett. 371:227-230.

González-Ramón, N., K. Hoebe, M. A. Alava, L. van Leengoed, M. Piñeiro, S. Carmona, M. Iturralde, F. Lampreave, and A. Piñeiro. 2000. Pig MAP/ITIH4 and haptoglobin are interleukin-6-dependent acute-phase plasma proteins in porcine primary cultured hepatocytes. Eur. J. Biochem. 267:1878-1885.

Grönlund, U., C. Hulten, P. D. Eckersall, C. Hogarth, and K. W. Persson. 2003. Haptoglobin and serum amyloid A in milk and serum during acute and chronic experimentally induced Staphylococcus aureus mastitis. J. Dairy Res. 70:379-386.

Hagiwara, K., H. Yamanaka, K. Hisaeda, S. Taharaguchi, R. Kirisawa, and H. Iwai. 2001. Concentration of IL-6 in serum and whey from healthy and mastitic cows. Vet. Res. Commun. 25:99-108. 
Hashimoto, K., T. Tobe, J. Sumiya, Y. Sano, N. H. Choi-Miura, A. Ozawa, H. Yasue, and M. Tomita. 1996. Primary structure of the pig homologue of human IHRP inter-alpha-trypsin inhibitor family heavy chain-related protein. J. Biochem. 119:577-584.

Hiitiö, H., J. Vakkamäki, H. Simojoki, T. Autio, J. Junnila, S. Pelkonen, and S. Pyörälä. 2017. Prevalence of subclinical mastitis in Finnish dairy cows: Changes during recent decades and impact of cow and herd factors. Acta Vet. Scand. 59:22.

Hiss, S., M. Mielenz, R. M. Bruckmaier, and H. Sauerwein. 2004. Haptoglobin concentrations in blood and milk after endotoxin challenge and quantification of mammary $\mathrm{Hp}$ mRNA expression. J. Dairy Sci. 87:3778-3784.

Huang, J., G. Luo, Z. Zhang, X. Wang, Z. Ju, Ch. Qi, Y. Zhang, Ch. Wang, R. Li, J. Li, W. Yin, Y. Xu, S. J. Moisá, J. J. Loor, and J. Zhong. 2014. iTRAQ-proteomics and bioinformatics analyses of mammary tissue from cows with clinical mastitis due to natural infection with Staphylococcus aureus. BMC Genomics 15:839.

Kashyap, R. S., A. R. Nayak, P. S. Deshpande, D. Kabra, H. J. Purohit, G. M. Taori, and H. F. Daginawala. 2009. Inter-alpha-trypsin inhibitor heavy chain 4 is a novel marker of acute ischemic stroke. Clin. Chim. Acta 402:160-163.

Keefe, G. P. 1997. Streptococcus agalactiae mastitis: A review. Can. Vet. J. 38:429-437.

Kirkpatrick, M. A., and J. D. Olson. 2015. Somatic cell counts at first test: More than a number, in Proceedings. NMC Annu. Meet. 2015:53-56.

Lai, I. H., J. H. Tsao, Y. P. Lu, J. W. Lee, X. Zhao, F. L. Chien, and S. J. Mao. 2009. Neutrophils as one of the major haptoglobin sources in mastitis affected milk. Vet. Res. 40:17.

Lampreave, F., N. González-Ramón, S. Martínez-Ayensa, M. A. Hernandez, H. K. Lorenzo, A. García-Gil, and A. Piñeiro. 1994. Characterization of the acute phase serum protein response in pigs. Electrophoresis 15:672-676.

Lee, K. Y., P. H. Feng, S. C. Ho, K. J. Chuang, T. T. Chen, C. L. Su, W. T. Liu, and H. C. Chuang. 2015. Inter-alpha-trypsin inhibitor heavy chain 4: A novel biomarker for environmental exposure to particulate air pollution in patients with chronic obstructive pulmonary disease. Int. J. Chron. Obstruct. Pulmon. Dis. 10:831-841.

Miglio, A., L. Moscati, G. Fruganti, M. Pela, E. Scoccia, A. Valiani, and C. Maresca. 2013. Use of milk amyloid A in the diagnosis of subclinical mastitis in dairy ewes. J. Dairy Res. 80:496-502.

Moon, J. S., A. R. Lee, H. M. Kang, E. S. Lee, M. N. Kim, Y. H. Paik, Y. H. Park, Y. S. Joo, and H. C. Koo. 2007. Phenotypic and genetic antibiogram of methicillin-resistant staphylococci isolated from bovine mastitis in Korea. J. Dairy Sci. 90:1176-1185.

Murata, H., N. Shimada, and M. Yoshioka. 2004. Current research on acute phase proteins in veterinary diagnostic: An overview. Vet. J. 168:28-40.

National Mastitis Council. 2004. Microbiological Procedures for the Diagnosis of Bovine Udder Infection and Determination of Milk Quality. 4th ed. NMC, Madison, WI.

Nazifi, S., A. Khoshvaghti, and H. R. Gheisari. 2008. Evaluation of serum and milk amyloid A in some inflammatory diseases of cattle. Majallah-i Tahqiqat-i Dampizishki-i Iran 9:222-226.

Nielsen, B. H., S. Jacobsen, P. H. Andersen, T. A. Niewold, and P. M. H. Heegard. 2004. Acute phase protein concentrations in serum and milk from healthy cows, cows with clinical mastitis and cows with extramammary inflammatory conditions. Vet. Rec. 154:361365 .

Nishimura, H., I. Kakizaki, T. Muta, N. Sasaki, X. P. Pu, T. Yamashita, and S. Nagasawa. 1995. cDNA and deduced amino acid sequence of human PK-120, a plasma kallikrein-sensitive glycoprotein. FEBS Lett. 357:207-211.
Piñeiro, M., M. A. Alava, N. González-Ramón, J. Osada, P. Lasierra, L. Larrad, A. Piñeiro, and F. Lampreave. 1999. ITIH4 serum concentration increases during acute-phase processes in human patients and is up-regulated by interleukin-6 in hepatocarcinoma HepG2 cells. Biochem. Biophys. Res. Commun. 263:224-229.

Piñeiro, M., M. Andrés, M. Iturralde, S. Carmona, J. Hirvonen, S. Pyörälä, P. M. H. Heegaard, K. Tjørnehøj, F. Lampreave, A. Piñeiro, and M. A. Alava. 2004. ITIH4 (inter-alpha-trypsin inhibitor heavy chain 4) is a new acute-phase protein isolated from cattle during experimental infection. Infect. Immun. 72:3777-3782.

Saguchi, K., T. Tobe, K. Hashimoto, Y. Sano, Y. Nakano, N. H. Miura, and M. Tomita. 1995. Cloning and characterization of cDNA for inter-alpha-trypsin inhibitor family heavy chain-related protein (IHRP), a novel human plasma glycoprotein. J. Biochem. 117:14-18

Salier, J. P., P. Rouet, G. Raguenez, and M. Daveau. 1996. The inter$\alpha$-inhibitor family: From structure to regulation. Biochem. J 315:1-9.

Sarafan, N., J. P. Martin, J. Bourguignon, H. Borghi, A. Calle, R. Sesboue, and M. Diarra-Mehrpour. 1995. The human inter-alphatrypsin inhibitor genes respond differently to interleukin-6 in hepG2 cells. Eur. J. Biochem. 227:808-815.

Sinha, M. K., N. N. Thombare, and B. Mondal. 2014. Subclinical mastitis in dairy animals: Incidence, economics, and predisposing factors. Scient. World J. 2014:523984.

Sira, M. M., B. E. Behairy, A. M. Abd-Elaziz, S. A. Abd Elnaby, and E. E. Eltahan. 2014. Serum inter-alpha-trypsin inhibitor heavy chain (ITIH4) in children with chronic hepatitis C: Relations to liver fibrosis and viremia. Hepat. Res. Treat. 2014:307942.

Soler, L., N. García, M. Bochniarz, R. Dąbrowski, F. Lampreave, and M. A. Álava. 2018. Development of an ELISA for the measurement of the acute phase protein in inter alpha trypsin inhibitor heavy chain (ITIH4) in serum and milk samples from cows. Page 71 in Proceedings of the Fifth DairyCare Conference, Thessaloniki. DairyCare COST Action FA1308.

Song, M., and J. A. Kellum. 2005. Interleukin-6. Crit. Care Med. 33:S463-S465.

Subbannayya, Y., S. A. Mir, S. Renuse, S. S. Manda, S. M. Pinto, V. N. Puttamallesh, H. S. Solanki, H. C. Manju, N. Syed, R. Sharma, R. Christopher, M. Vijayakumar, K. V. V. Kumar, T. S. K. Prasad, G. Ramaswamy, R. V. Kumar, A. Chatterjee, A. Pandey, and H. Gowa. 2015. Identification of differentially expressed serum proteins in gastric adenocarcinoma. J. Proteomics 127:80-88.

Thielen, M. A., M. Mielenz, S. Hiss, and H. Sauerwein. 2005. Qualitative detection of haptoglobin mRNA in bovine and human leukocytes and bovine milk somatic cells. Vet. Med. 50:515-520.

Thielen, M. A., M. Mielenz, S. Hiss, H. Zerbe, W. Petzl, H. J. Schuberth, H. M. Seyfert, and H. Sauerwein. 2007. Short communication: Cellular localization of haptoglobin mRNA in the experimentally infected bovine mammary gland. J. Dairy Sci. 90:1215-1219.

Waller, K. P., A. Aspan, A. Nyman, Y. Persson, and U. G. Andersson. 2011. CNS species and antimicrobial resistance in clinical and subclinical bovine mastitis. Vet. Microbiol. 152:112-116.

Weber, A., A. T. Weber, T. L. McDonald, and M. A. Larson. 2006. Staphylococcus aureus lipotechoic acid induces differential expression of bovine serum amyloid A3 (SAA3) by mammary epithelial cells: Implications for early diagnosis of mastitis. Vet. Immunol. Immunopathol. 109:79-83.

Whist, A. C., O. Østerås, and L. Sølverød. 2007. Streptococcus dysgalactiae isolates at calving and lactation performance within the same lactation. J. Dairy Sci. 90:766-778. 